\title{
Research on Quality Model of Human Resource Management in Public Security Colleges
}

\author{
Liang $\mathrm{HU}^{1,2,{ }^{*}}$ \\ ${ }^{1}$ Department of humanities and management, JiangXi Police College, NanChang City, Jiangxi \\ Province, P.R.China \\ ${ }^{2}$ Collaborative Innovation Center for Economics crime investigation and prevention technology, \\ Jiangxi Province, P.R.China \\ ${ }^{*}$ Corresponding author
}

Keywords: Human resourse management, Public security, Quality model, College teacher.

\begin{abstract}
In the study field on the human resources management quality of the Chinese public security college, college teachers' evaluation and performance appraisal research is more and more, but the management and service education of teachers is not high, less research results. This article from the perspective of management and service, focus on Chinese public security colleges human resource management quality model (PU-HRMQ) based on personnel training and development and provides a theoretical method for evaluation of quality of human resource management in public security colleges.
\end{abstract}

\section{Introduction}

Human resources management belongs to the category of modern human resource management, human resource is organized according to the learning ability, physical and mental health, hobbies and work performance, make the evaluation process on the quality of human resource management, and provide a scientific basis for the selection of organization, management, human resources development and to realize the goals of the organization. University human resources as a special type of generalized human resource, especially the enterprise human resources and public security colleges' human resources evaluation have great difference, its particularity lies in the characteristics of this special type of organization in public security colleges. The public security colleges aims to cultivate social needs of the public security personnel, in order to maintain social order, and the other objectives of the organization are essentially different, and the enterprise's goal is to provide products and services for the society, realize the profit maximization[1][2].

The results of this research can be used in the horizontal comparison of the human resources of the same kind of police colleges and universities[3]. Provincial Public Security Colleges and comparison between the colleges and comparison between different regions in comparison between undergraduate and junior colleges, between the comparison, through comparison to find out the advantages and disadvantages of human resources in the construction of colleges and universities, so as to provide the direction for the development of the school. The results of this research can also be used for the longitudinal comparison of human resources in different periods of public Security colleges and universities[4][5]. By comparing with the evaluation of the starting year and the last year, we compared the human resource development plan of the school, and provided the reference for the decision-making of the school.

\section{Evaluation Index System}

Based on the research of human resource management, the domestic 3-5 public security colleges conducted field research, in-depth interviews with school personnel department, in the summary of human resource management on the basis of research results, the key process of the PU-HRMQ model for recruitment management, salary management, performance management, training 
management, employee relationship management, human resources the system of personnel information management and system management module, proposed model constraints and the quality of human resource management in public security colleges, through factor analysis, principal component analysis and cluster analysis methods of extracting key performance indicators of human resources management process quality.

The construction of the comprehensive evaluation system of human resources in Colleges and universities should accord with the theory of goal consistency, that is to say, it should be consistent between the three objectives of the organization, the evaluation index and the evaluation purpose. According to the requirements of the index design, according to the principle of the system, through the questionnaire survey of more than 50 colleges and universities, the construction of a comprehensive evaluation index system of the three levels, as shown in Table 1.

Table 1. Evaluation index system

\begin{tabular}{|c|c|c|}
\hline First layer index & Second layer index & Third layer index \\
\hline \multirow{10}{*}{$\operatorname{Teacher}\left(W_{l}\right)$} & \multirow{5}{*}{ General situation $\left(W_{l l}\right)$} & Teacher proportion \\
\hline & & Educational structure \\
\hline & & Title structure \\
\hline & & Age structure \\
\hline & & Post mobility \\
\hline & \multirow{5}{*}{ Personal situation $\left(W_{12}\right)$} & Moral character \\
\hline & & Teaching ability \\
\hline & & Scientific research ability \\
\hline & & Teamwork ability \\
\hline & & Communication skills \\
\hline \multirow{9}{*}{ Administrative staff $\left(W_{2}\right)$} & \multirow{4}{*}{ General situation $\left(W_{21}\right)$} & Administrative staff proportion \\
\hline & & Age structure \\
\hline & & Educational structure \\
\hline & & Post mobility \\
\hline & \multirow{5}{*}{ Personal situation $\left(W_{22}\right)$} & Working attitude \\
\hline & & Professional knowledge ability \\
\hline & & Work efficiency \\
\hline & & Work execution \\
\hline & & Innovation ability \\
\hline \multirow{8}{*}{ Support staff $\left(W_{3}\right)$} & \multirow{3}{*}{ General situation $\left(W_{31}\right)$} & Age structure \\
\hline & & Support staff proportion \\
\hline & & Post mobility \\
\hline & \multirow{5}{*}{ Personal situation $\left(W_{32}\right)$} & Business skills \\
\hline & & Service quality \\
\hline & & Work experience \\
\hline & & Task complexity \\
\hline & & Communication skills \\
\hline
\end{tabular}

\section{Evaluation Index Weight}

The index system is the main factor that affects the overall situation of human resources in colleges and universities, but its influence is not the same. In this paper, the analytic hierarchy process is used to construct the judgment matrix. Judgment matrix is the basic content of analytic hierarchy process (AHP)[6][7], and it is the core of determining the weight of each index in the matrix. The method of judging the importance of the first grade evaluation index is shown in Table 2. 
Table 2. Computation of first layer index

\begin{tabular}{|c|c|c|c|}
\hline Index & Teacher & $\begin{array}{c}\text { Administrative } \\
\text { staff }\end{array}$ & $\begin{array}{c}\text { Support } \\
\text { staff }\end{array}$ \\
\hline Teacher & $W_{1} / W_{1}$ & $W_{1} / W_{2}$ & $W_{1} / W_{3}$ \\
\hline $\begin{array}{c}\text { Administrative } \\
\text { staff }\end{array}$ & $W_{2} W_{1}$ & $W_{2} / W_{2}$ & $W_{2} / W_{3}$ \\
\hline Support staff & $W_{3} / W_{1}$ & $W_{3} / W_{2}$ & $W_{3} / W_{3}$ \\
\hline
\end{tabular}

Judgment matrix is expressed as the first level of the "teacher", "administrative staff" and "support staff" three indicators of compared. To determine the relative importance of the indexes in the comprehensive evaluation of university human resource system, compared with the "teacher" and "administrative management", which is more important indicators of school development goals, according to the importance of the corresponding points[7][8], as shown in Table 3.

Table 3. Standard degree of the judgment matrix

\begin{tabular}{|c|c|}
\hline Description & Value \\
\hline Two indicators compared to the same degree of importance & 1 \\
\hline Two indicators compared to an indicator is a little more important than another & 3 \\
\hline Two indicators compared to an indicator is significantly more important than another & 5 \\
\hline Two indicators compared to an indicator is very important than another & 7 \\
\hline Two indicators, an indicator than the other indicators of extreme importance & 9 \\
\hline
\end{tabular}

Through the normalization of the column vector of the judgment matrix, the characteristic vector, the maximum eigenvalue and the consistency test are computed, and the weight of the first level index is $0.545,0.273$ and 0.182 .

Table 4. First layer index

\begin{tabular}{|c|c|c|c|}
\hline & $\boldsymbol{W}_{\boldsymbol{I}}$ & $\boldsymbol{W}_{\mathbf{2}}$ & $\boldsymbol{W}_{\mathbf{3}}$ \\
\hline $\boldsymbol{W}_{\boldsymbol{1}}$ & 1 & 2 & 3 \\
\hline $\boldsymbol{W}_{\mathbf{2}}$ & $1 / 2$ & 1 & $3 / 2$ \\
\hline $\boldsymbol{W}_{\mathbf{3}}$ & $1 / 3$ & $2 / 3$ & 1 \\
\hline
\end{tabular}

Only the graded weights can not be applied directly in the quantitative evaluation, and the graded weights should be transformed into the total weight[9][10]. Among them, the total weight of the first level evaluation index is equal to the grading index weight, total weight of two level indexes is the product which belongs to the level of the index weight and the index weight, total weight of three level indexes is the product of the level indicators two indicators and the index weight. According to the above method, we can get the weight of each index, as shown in Table 5.

Table 5. Index weight of human resource management

\begin{tabular}{|c|c|c|c|c|c|}
\hline First layer index & $\mathbf{W}$ & Second layer index & $\mathbf{W}$ & Third layer index & $\mathbf{W}$ \\
\hline \multirow{8}{*}{$\operatorname{Teacher}\left(W_{l}\right)$} & \multirow{8}{*}{0.545} & \multirow{5}{*}{$\begin{array}{c}\text { General } \\
\operatorname{situation}\left(W_{I I}\right)\end{array}$} & \multirow{5}{*}{0.273} & Teacher proportion & 0.119 \\
\hline & & & & Educational structure & 0.060 \\
\hline & & & & Title structure & 0.040 \\
\hline & & & & Age structure & 0.030 \\
\hline & & & & Post mobility & 0.024 \\
\hline & & \multirow{3}{*}{$\begin{array}{c}\text { Personal } \\
\operatorname{situation}\left(W_{12}\right)\end{array}$} & \multirow{3}{*}{0.272} & Moral character & 0.068 \\
\hline & & & & Teaching ability & 0.068 \\
\hline & & & & Scientific research & 0.068 \\
\hline
\end{tabular}




\begin{tabular}{|c|c|c|c|c|c|}
\hline & & & & ability & \\
\hline & & & & Teamwork ability & 0.023 \\
\hline & & & & Communication skills & 0.045 \\
\hline \multirow{9}{*}{$\begin{array}{l}\text { Administrative } \\
\quad \operatorname{staff}\left(W_{2}\right)\end{array}$} & \multirow{9}{*}{0.273} & \multirow{4}{*}{$\begin{array}{c}\text { General } \\
\text { situation }\left(W_{21}\right)\end{array}$} & \multirow{4}{*}{0.091} & $\begin{array}{l}\text { Administrative staff } \\
\text { proportion }\end{array}$ & 0.026 \\
\hline & & & & Age structure & 0.026 \\
\hline & & & & Educational structure & 0.026 \\
\hline & & & & Post mobility & 0.013 \\
\hline & & \multirow{5}{*}{$\begin{array}{c}\text { Personal } \\
\text { situation }\left(W_{22}\right)\end{array}$} & \multirow{5}{*}{0.182} & Working attitude & 0.056 \\
\hline & & & & $\begin{array}{l}\text { Professional knowledge } \\
\text { ability }\end{array}$ & 0.056 \\
\hline & & & & Work efficiency & 0.027 \\
\hline & & & & Work execution & 0.018 \\
\hline & & & & Innovation ability & 0.044 \\
\hline \multirow{8}{*}{ Support staff $\left(W_{3}\right)$} & \multirow{8}{*}{0.182} & \multirow{3}{*}{$\begin{array}{c}\text { General } \\
\text { situation }\left(W_{31}\right)\end{array}$} & \multirow{3}{*}{0.061} & Age structure & 0.033 \\
\hline & & & & Support staff proportion & 0.017 \\
\hline & & & & Post mobility & 0.011 \\
\hline & & \multirow{5}{*}{$\begin{array}{c}\text { Personal } \\
\text { situation }\left(W_{32}\right)\end{array}$} & \multirow{5}{*}{0.121} & Business skills & 0.045 \\
\hline & & & & Service quality & 0.045 \\
\hline & & & & Work experience & 0.014 \\
\hline & & & & Task complexity & 0.010 \\
\hline & & & & Communication skills & 0.007 \\
\hline
\end{tabular}

The evaluation results can be used for the horizontal comparison of the human resources in similar universities. For example, a comparison between the provincial colleges and universities, the higher vocational colleges between different provinces, first-class colleges and universities and comparison between the comparison between new undergraduate colleges and so on. Through the comparison to find out the "short board" and "advantage" in the construction of human resources in order to indicate the direction of future development.

The evaluation results can also be used for the longitudinal comparison of human resources in different periods of the same university. By comparing with the evaluation of the beginning of the year and the last year of continuous dynamic comparison of the school's human resources development planning, to provide a reference for the decision-making of the school, so as to improve the scientific and feasibility of decision-making.

\section{Discussion and Future Work}

The university human resources management based on the characteristics of public security has a questionnaire survey and empirical research through the methods of literature research, the construction quality of human resource management model for public security institutions, key processes and key performance indicators of public security university human resource management quality.

Based on the background of domestic public security colleges, the quality of human resource management model has the characteristics of public security, a meaningful topic is the theory of human resource management that it is also an important direction of human resource management application, the subject for the enrichment and development of the theory of human resource management in our country, to improve the quality level of human resource management, especially is the theoretical value and significance to improve the ability of human resource management in public security colleges. 


\section{Acknowledgment}

This author's work is supported by JiangXi Science and Technology Research Project of Education Department (GJJ151193), JiangXi University Party Building Project (16DJQN065), JiangXi Police College Scientific Research Project (2016JGZB008) and JangXi Science Education Planning Project (17YB244).

This author's work also is supported by the Opening Project of Collaborative Innovation Center for Economics crime investigation and prevention technology, Jiangxi Province.

\section{References}

[1] Huang Juan. Study on the problems of College Teachers' teaching and education[D]. Wuhan: Wuhan University, 2004. (in Chinese)

[2] Yao Yingjun. Study on the construction of human resource management system of university teachers[J]. Science and Technology Prospect, 2016,26 (3): 173-237. (in Chinese)

[3] Ye Jun. on the construction of human resource management model in newly established local universities[J]. Journal of Shaoxing University, 2012, (7): 83-86. (in Chinese)

[4] Fu Feiqiang. Research on the evaluation index of human resources efficiency: Based on the human resource effectiveness scorecard model[J]. China Human Resource Development, 2013, (21): 33-39. (in Chinese)

[5] Liu Dawei. Research on human resource capacity measurement model and index system[J]. Productivity Research, 2008, (12): 60-63. (in Chinese)

[6] Yuan Xize, Zhang Jianming. The course of human resource management modular teaching design[J]. Journal of Hubei University of Police, 2015,28 (2): 157-160. (in Chinese)

[7] Song Liqu, Department of Jianping. Research on the model and system of human resource management in public security colleges[J]. Knowledge Economy, 2014, (18): 169-177. (in Chinese)

[8] Song Liqu, Si Jianping, Huo Nagano. Public Security College Teachers Human Resources Management Development Strategy Research[J]. Document, 2015, (5): 156-157. (in Chinese)

[9] Ding Qing. MVC design pattern in police human resource management information system[J]. Police Technology, 2007, (4): 42-43. (in Chinese)

[10] Fu Kai. The impact of community policing on human resources management of public security and its response[J]. Journal of Hubei University of Police, 2014,27 (8): 19-21. (in Chinese) 